\title{
SLC26A6 Gene
}

National Cancer Institute

\section{Source}

National Cancer Institute. SLC26A6 Gene. NCI Thesaurus. Code C114427.

This gene is involved in acid-base homeostasis. 